\title{
Process Optimization of Finger Millet Incorporated Extrudates
}

\author{
${ }^{a}$ Yadav KC*, ${ }^{a, b}$ Ranjit Rajbanshi, ${ }^{c}$ Prabesh Bhattarai, ${ }^{d}$ Pramesh K. Dhungana, ${ }^{e}$ Dilip Subba \\ ${ }^{a}$ Department of Food Technology, Central Campus of Technology, Tribhuvan University,Dharan, Nepal \\ ${ }^{\mathrm{b}}$ CG (Foods) Nepal Pvt. Ltd. Nawalparasi, Nepal \\ ${ }^{\mathrm{c}}$ Central Department of Food Technology, Institute of Science and Technology, Tribhuvan University, Nepal \\ ${ }^{\mathrm{d} S}$ School of Agriculture and Food Science, The University of Queensland, Australia \\ eNepal Academy of Science and Technology, Khumaltar, Lalitpur
}

\begin{abstract}
*Corresponding email: ykcdng504@gmail.com
Abstract

The effects of incorporation of finger millet (Eleusine coracana L.) flour and extrusion conditions on physico-chemical characteristics of corn grit- rice grit-chickpea flour blend expanded extrudates were studied. Response surface methodology was used to study the effects of level of incorporation of millet flour in feed composition (5 to $25 \%$ ), feed moisture (12-16\%), screw speed (1000-1400 rpm) and extrusion temperature $\left(80-120^{\circ} \mathrm{C}\right)$. Single screw extruder was used for the experiments. The level of millet flour incorporation had significant effect on water solubility index $(\mathrm{p}<0.05)$, water absorption index $(\mathrm{p}<0.05)$ and starch digestibility $(\mathrm{p}<0.001)$. Feed moisture had significant effect on water solubility index $(\mathrm{p}<0.001)$ and water absorption index $(\mathrm{p}<0.05)$. Extrusion temperature had significant effect on water solubility index $(p<0.001)$, water absorption index $(p<0.05)$ and starch digestibility $(\mathrm{p}<0.05)$. Screw speed had significant effect on water solubility index $(\mathrm{p}<0.001)$ and water absorption index $(\mathrm{p}<0.05)$. Numerical optimization study predicted $106.8{ }^{\circ} \mathrm{C}$ of extrusion temperature, $1253 \mathrm{rpm}$ of screw speed, $12.67 \%$ of feed moisture, and $22.8 \%$ of millet flour as optimum conditions to produce acceptable extrudates from the feed composite containing millet flour.
\end{abstract}

\begin{tabular}{l} 
Article Info \\
\hline Article history: \\
Received date: 30 June 2020 \\
Accepted date: 25 July 2020 \\
\hline \\
Keywords: \\
Response Surface Methodology, \\
Single crew extrusion, \\
Millet flour, \\
Water absorption index, \\
Water solubility index, \\
Starch digestibility
\end{tabular}

\section{Introduction}

Extrusion cooking is a specialized form of processing which involves heating to high temperatures in short time with the application of mechanical mixing and shearing, before finally extruding to form a structure (Guy, 2001). Cereals are the main raw material for extruded snack foods. Millets (Eleusine coracana L.) are predominantly starchy. The revitalized nutritional strengths of millets have made them functional grains. Snacks and pasta developed by extrusion process from the millet are found to be highly acceptable and hypo-glycemic (Rao et al., 2016). Chickpea flour has also been widely used in extrudates. However, contradictory effects have been reported regarding the properties of extrudates with chickpea flour. Shirani and Ganesharanee (2009) found that the addition of chickpea flour on extrudates significantly reduced lateral expansion of extrudate. In contrast, Meng et al. (2010) found positive correlation between the amount of chickpea flour and lateral expansion in a work related to multiple blends of chickpea flour, potato starch, protein concentrate, and other additives. Anderson (1969) found that water absorption index (WAI) of extruded maize flour increased progressively with increased extrusion temperature and increased feed moisture. Ilo et al. (1999) reported that the degree of gelatinization of extruded maize grits decreased with increasing feed moisture, and increased with increasing feed rate and product temperature. Artz et al. (1990) reported that there was decrease of WAI in extrusion of corn fiber and corn starch blend. For rice based extrudates by (Ding et al., 2005) and for maize, finger millet extrudates by (Onyango et al, 2004) found that water solubility index (WSI) value decreased with increasing feed moisture content. Increase in cassava flour level was found to decrease WAI and WSI (KC et al., 2015). The increase in WSI with increasing screw speed was consistent with the results reported for corn meal and corn and wheat extrudates (Jin et al., 1995; Mezreb et al., 2003). The effect of extrusion conditions on WAI had been discussed by (Colonna and Mercier, 1983; (Gomez and Aguilera, 1983); 
Pelembe et al., 2002; Ding et al., 2006; and many other researchers. Guha et al. (1998) studied structural change in starch chain due to extrusion temperature. Similarly, Fletcher et al. (1985), Wen et al. (1990), Camire and King (1991), Gutkoski and El-Dash (1999) and other many researchers studied the effect on WSI. The effect of millet flour on major commercial extrusion ingredients such as corn grits, rice grits and chickpea flour has not been fully assessed yet. This research is focused on evaluating effects of millet incorporation in properties of extrudates based on rice grits, corn grits and chickpea flour and optimizing the process parameters.

\section{Materials and Methods}

\subsection{Ingredients selection and preparation}

Corn grit, rice grit and chick-pea flour ( $\mathrm{Cg}-\mathrm{Rg}-\mathrm{CpF})$ blend was used for extrusion while finger millet (kodo) flour (MF) at different proportion (Table 1) was incorporated by replacing corn grit. Millet that was stored six months after harvest was purchased from Pancha-kanya, Sunsari, Nepal and sun dried. Moisture content of millet was determined frequently unless it was reduced to $6 \%$. Millet was milled and its flour was packaged in high density polyethylene (HDPE) bag of $30 \mu \mathrm{m}$ and sealed. Other ingredients were supplied from CG foods (Nepal) Pvt. Ltd. Nawalparasi and packaged in HDPE.

\subsection{Experimental design}

Response surface methodology (RSM) was used for the experimental design using a five-level, four-factor Central Composite Rotatable Design (Myers et al., 2016). RSM can be used for the modeling and analysis of the problem in which response of the interest is influenced by several variables. The independent variables selected for the experiments were: Feed proportion, moisture content, screw speed, and extrusion temperature. Response variables were water absorption index, Water solubility index and maltose content. For numerical multi-response optimization, results of response variables; bulk density (0.23-0.46 $\mathrm{g} / \mathrm{cm} 3)$ and lateral expansion (91.11-144\%) were used from the similar research of millet incorporated extrusion (KC et al., 2013).

\subsection{Extrusion of composite blends}

Ingredient formulations and experimental combinations for extrusion products are given in Table 1. In the blend preparation millet flour at levels of 5\%, $10 \%, 15 \%, 20 \%$ and $25 \%$ were used. The moisture was adjusted by sprinkling distilled water in all the dry ingredients. All the ingredients were weighed and then mixed with the help of small scale mixture (Flightier series 003, Teflon, India) for $20 \mathrm{~min}$. This mixture was then passed through a $2 \mathrm{~mm}$ sieve to reduce the lumps formed due to addition of moisture. After mixing samples were stored in polyethylene bags (HDPE, $30 \mu \mathrm{m})$ and were kept in high precision $\left(+0.1{ }^{\circ} \mathrm{C}\right)$ incubator (Macro Scientific works, New Delhi) at 45 ${ }^{\circ} \mathrm{C}$ for $12 \mathrm{~h}$ duration for the stabilization of moisture. Moisture content was measured by I-R moisture meter (MB35 Halogen OHAUS) of CG foods (Nepal), Nawalparasi. The single screw extruder was kept running for $30 \mathrm{~min}$ to stabilize the set temperatures and feed of $1 \mathrm{~kg}$ with different proportions of corn grit and millet flour (Table 1) were then poured into feed hopper. The feed rate of extruder was adjusted to 4 $\mathrm{kg} / \mathrm{h}$. The die diameter of $3 \mathrm{~mm}$ was selected as recommended by the manufacturer. The product collected at the die end and moisture content of the products was determined frequently unless it was reduced to $6 \%$. Then, it was packed air-tight in polythene (HDPE, 30 $\mu \mathrm{m}$ ) for analysis.

\subsection{Evaluation of extrudates characteristics}

Water absorption Index (WAI) and Water Solubility Index (WSI) were determined according to the method developed for cereals (Anderson, 1969). The ground extrudate was suspended in water at room temperature for $30 \mathrm{~min}$, gently stirred during this period, and then centrifuged at $3000 \mathrm{rpm}$ for $15 \mathrm{~min}$. The supernatant was decanted into an evaporating dish of known weight. The WAI was the weight of gel obtained after removal of the supernatant per unit weight of original dry solids. The WSI was the weight of dry solids in the supernatant expressed as a percentage of the original weight of sample. Reducing sugar (maltose content) was estimated by DNS method (Garriga et al., 2017) for starch digestibility of the extrudate. One $\mathrm{mL}$ standard maltose solution was pipetted out in different test tubes and make up the volume of all test tubes to $3 \mathrm{~mL}$ with distilled water. One mL DNS reagent was added to all the test tubes and the tubes were taken to a bath thermostatized at 100 ${ }^{\circ} \mathrm{C}$ for $5 \mathrm{~min}$. Final volume was made $10 \mathrm{~mL}$ and homogenized. After cooling to room temperature, UV absorbance was read at $540 \mathrm{~nm}$ against the blank.

$$
\begin{gathered}
W A I=\frac{\text { Weight gain by gel }}{\text { Dryweight of extrudate }} \\
W S I(\%)=\frac{\text { Weight of dry solid in Supernant }}{\text { Dryweight of extudate }} \times 100
\end{gathered}
$$


Table 1: Experimental combinations in Coded and Uncoded levels for millet flour with rice grit, corn grit and chick-pea flour based extrudates

\begin{tabular}{|c|c|c|c|c|c|c|c|c|}
\hline \multirow{2}{*}{$\begin{array}{l}\text { S. } \\
\text { No. }\end{array}$} & \multicolumn{4}{|c|}{ Coded variables } & \multirow[b]{2}{*}{ Feed Proportion (\%) } & \multicolumn{3}{|c|}{ Uncoded variables } \\
\hline & $\mathbf{A}$ & B & C & D & & Feed Moisture (\%) & Temperature $\left({ }^{\circ} \mathbf{C}\right)$ & Screw speed (rpm) \\
\hline 1 & -1 & -1 & -1 & -1 & $58: 32: 10$ & 13 & 90 & 1100 \\
\hline 2 & 1 & -1 & -1 & -1 & $58: 22: 20$ & 13 & 90 & 1100 \\
\hline 3 & -1 & 1 & -1 & -1 & $58: 32: 10$ & 15 & 90 & 1100 \\
\hline 4 & 1 & 1 & -1 & -1 & $58: 22: 20$ & 15 & 90 & 1100 \\
\hline 5 & -1 & -1 & 1 & -1 & $58: 32: 10$ & 13 & 110 & 1100 \\
\hline 6 & 1 & -1 & 1 & -1 & $58: 22: 20$ & 13 & 110 & 1100 \\
\hline 7 & -1 & 1 & 1 & -1 & $58: 32: 10$ & 15 & 110 & 1100 \\
\hline 8 & 1 & 1 & 1 & -1 & $58: 22: 20$ & 15 & 110 & 1100 \\
\hline 9 & -1 & -1 & -1 & 1 & $58: 32: 10$ & 13 & 90 & 1300 \\
\hline 10 & 1 & -1 & -1 & 1 & $58: 22: 20$ & 13 & 90 & 1300 \\
\hline 11 & -1 & 1 & -1 & 1 & $58: 32: 10$ & 15 & 90 & 1300 \\
\hline 12 & 1 & 1 & -1 & 1 & $58: 22: 20$ & 15 & 90 & 1300 \\
\hline 13 & -1 & -1 & 1 & 1 & $58: 32: 10$ & 13 & 110 & 1300 \\
\hline 14 & 1 & -1 & 1 & 1 & $58: 22: 20$ & 13 & 110 & 1300 \\
\hline 15 & -1 & 1 & 1 & 1 & $58: 32: 10$ & 15 & 110 & 1300 \\
\hline 16 & 1 & 1 & 1 & 1 & $58: 22: 20$ & 15 & 110 & 1300 \\
\hline 17 & -2 & 0 & 0 & 0 & $58: 37: 05$ & 14 & 100 & 1200 \\
\hline 18 & 2 & 0 & 0 & 0 & $58: 17: 25$ & 14 & 100 & 1200 \\
\hline 19 & 0 & -2 & 0 & 0 & $58: 27: 15$ & 12 & 100 & 1200 \\
\hline 20 & 0 & 2 & 0 & 0 & $58: 27: 15$ & 16 & 100 & 1200 \\
\hline 21 & 0 & 0 & -2 & 0 & $58: 27: 15$ & 14 & 80 & 1200 \\
\hline 22 & 0 & 0 & 2 & 0 & $58: 27: 15$ & 14 & 120 & 1200 \\
\hline 23 & 0 & 0 & 0 & -2 & $58: 27: 15$ & 14 & 100 & 1000 \\
\hline 24 & 0 & 0 & 0 & 2 & $58: 27: 15$ & 14 & 100 & 1400 \\
\hline 25 & 0 & 0 & 0 & 0 & $58: 27: 15$ & 14 & 100 & 1200 \\
\hline 26 & 0 & 0 & 0 & 0 & $58: 27: 15$ & 14 & 100 & 1200 \\
\hline 27 & 0 & 0 & 0 & 0 & $58: 27: 15$ & 14 & 100 & 1200 \\
\hline 28 & 0 & 0 & 0 & 0 & $58: 27: 15$ & 14 & 100 & 1200 \\
\hline 29 & 0 & 0 & 0 & 0 & $58: 27: 15$ & 14 & 100 & 1200 \\
\hline 30 & 0 & 0 & 0 & 0 & $58: 27: 15$ & 14 & 100 & 1200 \\
\hline
\end{tabular}

Note: Feed composition [(50\% rice grit $+8 \%$ chick-pea flour $)$ : corn grit: millet flour $),$ Where $X=(50 \%$ rice grit $+8 \%$ chickpea flour) was kept constant.

\subsection{Data analysis}

The responses (WAI, WSI and starch digestibility) for different experimental combinations were related to the coded variables by a second degree polynomial equation:

$$
Y=\beta o+\beta 1 A+\beta 2 B+\beta 3 C+\beta 4 D+\beta 11 A 2+\beta 22 B 2
$$
$+\beta 33 C 2+\beta 44 D 2+\beta 12 A B+\beta 13 A C+\beta 14 A D+\beta 23$ $B C+\beta 24 B D+\beta 34 C D+\varepsilon$

Where $\mathrm{A}, \mathrm{B}, \mathrm{C}$ and $\mathrm{D}$ are the coded values of independent variables namely feed composition (\% millet flour), feed moisture content $(\%)$, extrusion temperature $\left({ }^{\circ} \mathrm{C}\right)$ and screw speed (rpm), respectively. The coefficients of the polynomial were represented by $\beta$ o (intercept); $\beta 1, \beta 2, \beta 3, \beta 4$ (coefficient of linear effects), $\beta 12, \beta 13, \beta 14, \beta 23, \beta 24, \beta 34$ (coefficient of interaction effects); $\beta 11, \beta 22, \beta 33, \beta 44$ (coefficient of quadratic effects); and $\varepsilon$ (random error). Design Expert software (STAT-EASE Inc., USA, version 6.0) was used to analyze data and optimization.

\subsection{Optimization study}

A numerical multi-response optimization technique was applied to determine the optimum combination of millet flour in feed composition, feed moisture, screw 
speed and extrusion temperature for the development of extrudate containing corn grit, rice grit, chick-pea flour and millet flour. The assumptions were to develop a product which would have maximum expansion, minimum bulk density, maximum WAI, WSI content in range and maltose content in range. Responses were maintained as mentioned whereas independent variables were kept within range.

\section{Results and Discussion}

\subsection{Effects of process variables on WAI}

The WAI ranged from 5.40 to $6.99 \mathrm{~g} / \mathrm{g}$. Table 2 shows the coefficients of the model and statistical attributes of WAI. All the linear terms except moisture content had negative effect on WAI. The decrease in millet flour proportion will increase the WAI of the product. This might be attributing to relative decrease in fiber content with addition of millet flour and competition of absorption of water between millet flour and available starch. Similar findings were reported by (Artz et al., 1990) in extrusion of corn fiber and corn starch blend. At highest temperature the WAI value was found to be increased with increase in feed moisture (Fig 1). This might be due to higher moisture content, acting as a plasticizer during extrusion cooking, reduces the degradation of starch granules and this result in an increased capacity for water absorption. This decrease in WAI values with an increase in temperature might be due to an increase in starch decomposition degradation (Colonna and Mercier, 1983). It was stated that WAI decreases with increasing temperature if dextrinization or starch melting prevails over the gelatinization phenomenon (Ding et al., 2006; Pelembe et al., 2002). Increase in screw speed will decrease WAI. The reduction of WAI by increasing screw speed might be due to starch degradation. At a low shear rate (low screw speed) and/or low temperature, there might be less damaged polymer chains and a greater availability of hydrophilic groups which can bind more water resulting in higher values of WAI (Gomez and Aguilera, 1983). WAI was affect by the extrusion temperature and screw speed. The higher water absorption index was observed at high extrusion temperature and low screw speed conditions from (Fig 2). This might be due to high residence time at low screw speed permitting enhanced extent of cooking. Only gelatinized starch granules absorb water at room temperature and swell; however, starch fragmentation increases when the gelatinization degree increases thus decreasing water absorption.

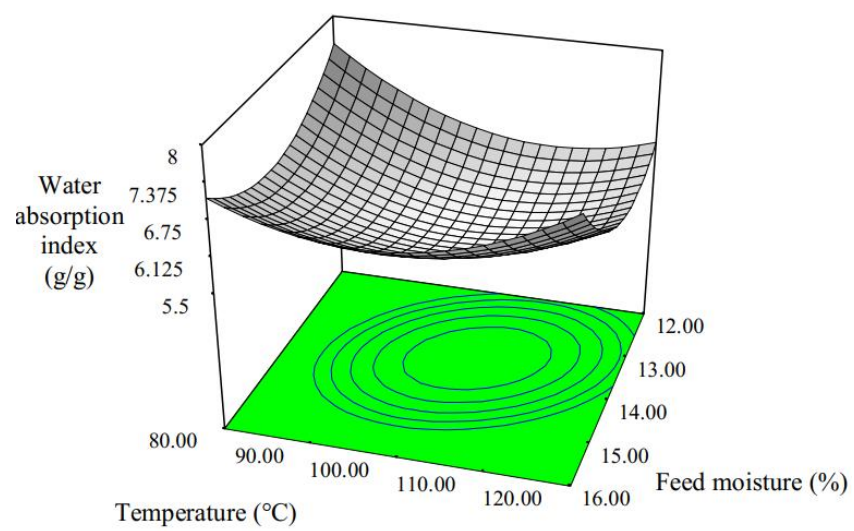

Fig. 1: Response surface plot for water absorption index as a function of feed moisture and extrusion temperature at center value of feed composition and screw speed.

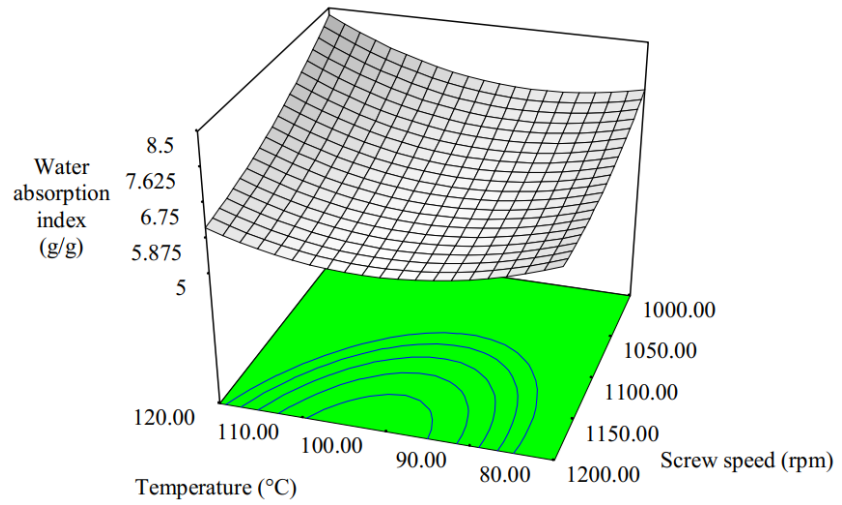

Fig. 2: Response surface plot for water absorption index as a function of screw speed and extrusion temperature at center value of feed moisture and feed composition

\subsection{Effects of process variables on WSI}

The WSI values ranged from $4.72 \%$ to $9.705 \%$. Table 2 shows the coefficients of the model and statistical attributes of WSI. All the linear terms except screw speed had negative effect on WSI. At higher level of millet flour in the feed blend, the WSI is found to be decreased with increasing moisture content (Fig 3) .This decrease with the increase in moisture content may be attributed to reduction in lateral expansion due to plasticization of melt as observed by (Ding et al., 2005). WSI was increased as millet content decreases. The feed blend was the mixture of corn grit, rice grit, chick-pea flour and millet flour. Proportion of rice grit and chick-pea flour was kept constant and hence there was increase in corn grit which contain high amount of fiber which may bind water more strongly than starch during extrusion. This water binding capacity inhibits water loss at the die, that is, at the exit of the extruder, reducing expansion (Camire and King, 1991); thus the starch present may cause degradation increasing WSI. WSI was found to be decreased with increasing temperature and decreasing screw speed (Fig 4). WSI depends on mainly on amylopectin content (quantity of 
soluble matter) which increases due to the degradation of starch. The high mechanical shear stress degraded macromolecules, the molecular weight of starch granules decreased and consequently, the WSI increased because degraded starch granules are more soluble in water (Fletcher et al., 1985). The increase in WSI with increasing screw speed was consistent with the results reported for corn meal and corn and wheat extrudates (Jin et al., 1995; Mezreb et al., 2003). Mezreb et al., (2003) reported that the increase of screw speed induced a sharp increase of specific mechanical energy, the high mechanical shear degraded macromolecules, and so the molecular weight of starch granules decreased and hence increased WSI. Wen et al., (1990) indicated that screw speed had a direct effect on size distribution of polysaccharide. A higher screw speed (increasing the shear) resulted in more fragmentation than a lower screw speed. WSI decreased significantly with increasing extrusion temperature. Gutkoski and El-Dash (1999) observed similar behavior in extruded oat products.

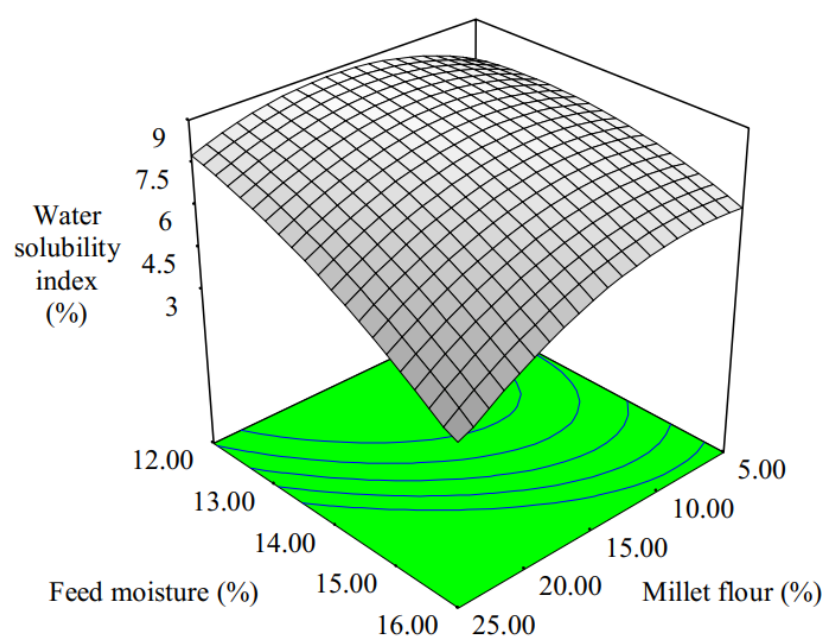

Fig. 3: Response surface plots for the variation of water solubility index as function of feed composition and feed moisture at central level of extrusion temperature and screw speed.

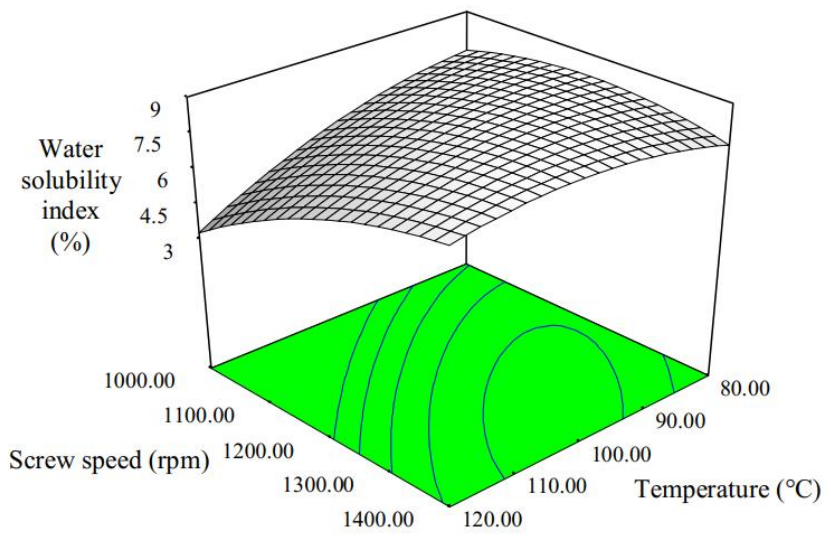

Fig. 4: Response surface plots for the variation of water solubility index as function of screw speed and extrusion temperature at central level of feed composition and feed moisture

\subsection{Effects of process variables on product starch digestibility $(S D)$}

Extrusion cooking is one processing method that has been used to modify the digestible characteristics of starchy materials. The amount of starch digestion was determined by comparing the absorbance of each sample to a standard Reducing sugar (maltose). Maltose content of an extruded product directly reflects the degree of gelatinization during extrusion. Maltose content of extrudate varied from 256.5 to $314.5 \mu \mathrm{g}$. Table 2 shows the coefficients of the model and statistical attributes of Maltose content. Among the linear terms, feed composition and extrusion temperature had significant positive effect on Maltose content. One factor plot for feed composition is shown in (Fig. 5). Maltose content of extrudates was found to increase with increased feed composition. Increase in millet flour increases the availability of starch. Maltose content is directly related with amount of starch present in raw material. Positive effect of feed composition indicates that the highest millet flour causes high gelatinized extrudate. This result is supported by trends in expansion ration with respect to feed composition. Increase in millet flour caused increase in expansion ratio. Expansion ratio is also a degree of gelatinization dependent factor. Study showed starch digestion (maltose content) increased with increase in temperature at increased proportion of millet flour in feed blend as shown in (Fig. 6). Higher temperature might have favored hydrolytic breakage of starch chains along with formation of shorter chain during gelatinization (Guha et al., 1998). 
Table 2: Regression coefficients of second order polynomial and their significance for dependent variables

\begin{tabular}{|c|c|c|c|c|c|c|c|c|c|}
\hline \multirow[t]{2}{*}{ Factors } & \multicolumn{3}{|c|}{ Water absorption index (WAI) } & \multicolumn{3}{|c|}{ Water solubility index (WSI) } & \multicolumn{3}{|c|}{$\begin{array}{l}\text { Starch digestibility (SD) } \\
\text { (Maltose content) }\end{array}$} \\
\hline & Coefficient & F value & $P$ value & Coefficient & F value & $P$ value & Coefficient & F value & $P$ value \\
\hline Intercepts & 5.564383 & 15.27606 & $<0.0001 * *$ & * $\quad 7.95$ & 15.01998 & $<0.0001 * *$ & 265.917 & 8.309 & $0.0001 * *$ \\
\hline A & -0.086 & 6.343322 & $0.0236^{*}$ & -0.39164 & 14.96646 & $0.0015^{*}$ & 8.142 & 49.028 & $<0.0001 * *$ \\
\hline B & 0.12123 & 12.59992 & $0.0029^{*}$ & -0.77728 & 58.95243 & $<0.0001 * *$ & -2.267 & 3.800 & 0.0702 \\
\hline $\mathrm{C}$ & -0.0754 & 4.877019 & $0.0432 *$ & -0.44202 & 19.06465 & $0.0006^{* *}$ & 3.608 & 9.630 & $0.0073 *$ \\
\hline $\mathrm{D}$ & -0.1061 & 9.64497 & $0.0072 *$ & 0.565746 & 31.23126 & $<0.0001 * *$ & -0.392 & 0.113 & 0.7409 \\
\hline$A^{2}$ & 0.17533 & 30.11959 & $<0.0001 * *$ & -0.29205 & 9.511373 & $0.0076^{*}$ & 6.402 & 34.646 & $<0.0001 * *$ \\
\hline $\mathrm{B}^{2}$ & 0.20978 & 43.12033 & $<0.0001 * *$ & -0.16955 & 3.205658 & 0.0936 & 2.715 & 6.229 & $0.0247 *$ \\
\hline$C^{2}$ & 0.19141 & 35.89864 & $<0.0001 * *$ & -0.18705 & 3.901563 & 0.0669 & 0.090 & 0.007 & 0.9354 \\
\hline$D^{2}$ & 0.31473 & 97.05671 & $<0.0001 * *$ & -0.1958 & 4.275129 & 0.0564 & -0.660 & 0.369 & 0.5528 \\
\hline $\mathrm{AB}$ & -0.093 & 4.948088 & $0.0419 *$ & -0.22854 & 3.397697 & 0.0851 & -3.600 & 6.390 & $0.0232 *$ \\
\hline $\mathrm{AC}$ & -0.01 & 0.05752 & 0.8137 & 0.311093 & 6.295563 & $0.0241^{*}$ & -1.663 & 1.363 & 0.2613 \\
\hline $\mathrm{AD}$ & 0.0086 & 0.042317 & 0.8398 & 0.263848 & 4.528574 & 0.0503 & 1.838 & 1.665 & 0.2165 \\
\hline $\mathrm{BC}$ & 0.10473 & 6.268653 & $0.0243 *$ & 0.889729 & 51.49567 & $<0.0001 * *$ & -2.338 & 2.694 & 0.1215 \\
\hline $\mathrm{BD}$ & 0.0779 & 3.468076 & 0.0823 & -0.03694 & 0.088785 & 0.7698 & -0.712 & 0.250 & 0.6241 \\
\hline $\mathrm{CD}$ & -0.1666 & 15.85542 & $0.0012 *$ & 0.28164 & 5.159934 & $0.0383^{*}$ & 0.975 & 0.469 & 0.5040 \\
\hline $\mathrm{R}^{2}$ & & 0.93 & & & 0.933 & & & 0.88 & \\
\hline Adj. $R^{2}$ & & 0.87 & & & 0.871 & & & 0.77 & \\
\hline Adeq precision & & 12.43 & & & 15.13 & & & 13.13 & \\
\hline Lack of fit & & 2.26 & 0.19 & & 1.7 & & .28 & 0.75 & 0.66 \\
\hline
\end{tabular}

*Significant at $P<0.05, * *$ Significant at $P<0.001$

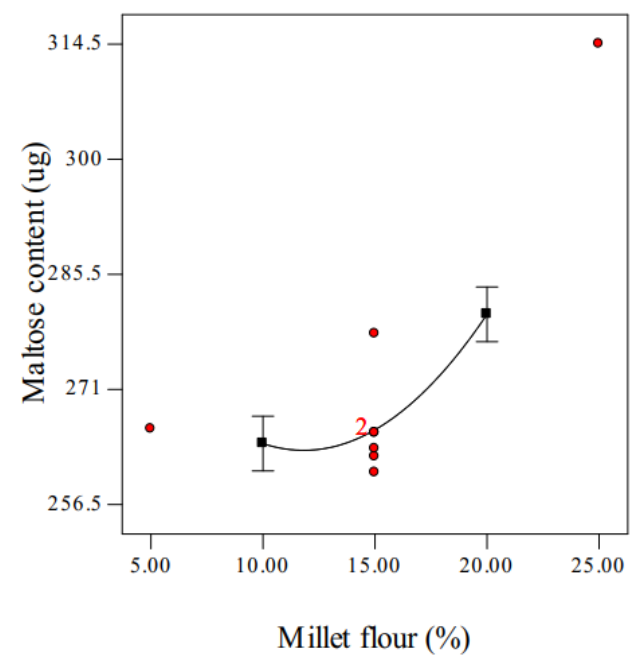

Fig. 5: One factor plot for the variation of maltose content of extrudates as function of feed composition

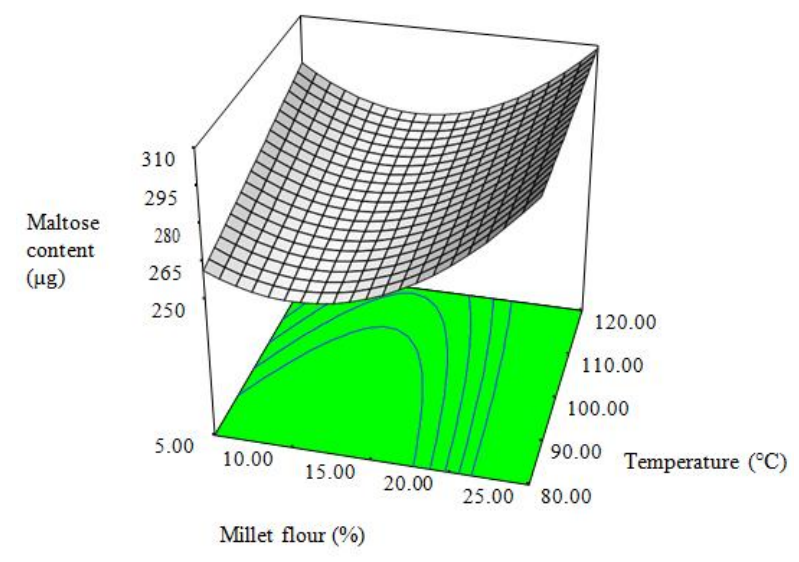

Fig. 6: Response surface plot for maltose content as a function of extrusion temperature and feed composition at center value of feed moisture and screw speed.

The suitability of the model developed for predicting the optimum response values was tested using the recommended optimum conditions of the variables and was also used to validate experimental and predicted values of the responses. The results of the different physic-chemical properties of extrudate are shown in Table 4. 
Table 3: Multi response optimization constraints of extrudates with millet flour

\begin{tabular}{llrcccc}
\hline \multicolumn{1}{c}{ Name } & $\begin{array}{r}\text { Goal } \\
\end{array}$ & $\begin{array}{r}\text { Lower } \\
\text { Limit }\end{array}$ & $\begin{array}{c}\text { Upper } \\
\text { Limit }\end{array}$ & \multicolumn{2}{c}{$\begin{array}{c}\text { Lower Upper Impor } \\
\text { weight weight }\end{array}$} \\
\hline Millet flour $(\%)$ & Max & 5 & 25 & 1 & 1 & 3 \\
Feed moisture $(\%)$ & $\mathrm{R}$ & 12 & 16 & 1 & 1 & 3 \\
Temperature $\left({ }^{\circ} \mathrm{C}\right)$ & $\mathrm{R}$ & 80 & 120 & 1 & 1 & 3 \\
Screw speed $(\mathrm{rpm})$ & $\mathrm{R}$ & 1000 & 1400 & 1 & 1 & 3 \\
$\mathrm{LE}(\%)$ & $\mathrm{Max}$ & 91.11 & 144.0 & 1 & 1 & 3 \\
$\mathrm{BD}\left(\mathrm{g} / \mathrm{cm}^{3}\right)$ & Min & 0.23 & 0.46 & 1 & 1 & 3 \\
WSI $(\%)$ & Max & 4.72 & 9.71 & 1 & 1 & 3 \\
WAI $(\mathrm{g} / \mathrm{g})$ & Min & 5.40 & 7.00 & 1 & 1 & 3 \\
\multicolumn{2}{l}{ Maltose content $(\mu \mathrm{g})$ Max } & 256.5 & 314.50 & 1 & 1 & 3 \\
\hline
\end{tabular}

Max (Maximize), R (Range), (Min) Minimize

Table 4: Predicted and actual values of the responses at the optimized condition

\begin{tabular}{lccc}
\hline Responses & $\begin{array}{c}\text { Predicted } \\
\text { values }\end{array}$ & $\begin{array}{c}\text { Actual } \\
\text { values }\end{array}$ & $\begin{array}{c}\text { \% deviation } \\
\text { from predicted } \\
\text { value }\end{array}$ \\
\hline Lateral expansion $(\%)$ & 141.57 & 152.76 & 7.9 \\
Bulk density $\left(\mathrm{gm} / \mathrm{cm}^{3}\right)$ & 0.231 & 0.21 & 9.09 \\
WSI $(\%)$ & 7.56 & 6.9 & 8.7 \\
WAI $(\mathrm{g} / \mathrm{g})$ & 6.12 & 6.7 & 9.4 \\
Maltose content $(\mu \mathrm{g})$ & 314.5 & 295 & 6.2 \\
\hline
\end{tabular}

\section{Conclusions}

The results revealed that the WAI, WSI and starch digestibility (on the basis of maltose content) were almost equally affected by the variation of millet composition, temperature, screw speed and extrusion temperature. WSI was found decreased with increase in millet incorporation, feed moisture and extrusion temperature but was directly proportional to screw speed. Similarly, WAI decreased with increase in millet incorporation, extrusion temperature and screw speed but was directly proportional to feed moisture. SD increased with increase in millet incorporation and screw speed. Optimizing the process variables could play key role in enhancing the functional properties of extrudates.

\section{Conflicts of Interest}

No any conflict of interest.

\section{Funding}

This research received no external funding.

\section{References}

Anderson, R. A. (1969). Gelatinization of corn grits by roll-and extrusion-cooking. Cereal science today, 14, 4-12.
Artz, W. E., Warren, C., \& Villota, R. (1990). Twinscrew extrusion modification of a corn fiber and corn starch extruded blend. Journal of Food Science, 55(3), 746-754.

Camire, M. E., \& King, C. C. (1991). Protein and fiber supplementation effects on extruded cornmeal snack quality. Journal of Food Science, 56(3), 760763.

Colonna, P., \& Mercier, C. (1983). Macromolecular modifications of manioc starch components by extrusion-cooking with and without lipids. Carbohydrate Polymers, 3(2), 87-108.

Ding, Q. B., Ainsworth, P., Plunkett, A., Tucker, G., \& Marson, H. (2006). The effect of extrusion conditions on the functional and physical properties of wheat-based expanded snacks. Journal of food engineering, 73(2), 142-148.

Ding, Q. B., Ainsworth, P., Tucker, G., \& Marson, H. (2005). The effect of extrusion conditions on the physicochemical properties and sensory characteristics of rice-based expanded snacks. Journal of Food engineering, 66(3), 283-289.

Fletcher, S. I., Richmond, P., \& Smith, A. C. (1985). An experimental study of twin-screw extrusioncooking of maize grits. Journal of Food Engineering, 4(4), 291-312.

Garriga, M., Almaraz, M., \& Marchiaro, A. (2017). Determination of reducing sugars in extracts of Undaria pinnatifida (harvey) algae by UV-visible spectrophotometry (DNS method). Actas De Ingenieria, 3, 173-179.

Gomez, M. H., \& Aguilera, J. M. (1983). Changes in the starch fraction during extrusion-cooking of corn. Journal of Food Science, 48(2), 378-381.

Guha, M., Ali, S. Z., \& Bhattacharya, S. (1998). Effect of barrel temperature and screw speed on rapid viscoanalyser pasting behaviour of rice extrudate. International Journal of Food Science \& Technology, 33(3), 259-266.

Gutkoski, L. C., \& El-Dash, A. A. (1999). Effect of extrusion process variables on physical and chemical properties of extruded oat products. Plant Foods for Human Nutrition, 54(4), 315-325.

Guy, R. (2001). Extrusion cooking: technologies and applications. Woodhead publishing Limited, Abington Hall. [1855735598]. 
Ilo, S., Liu, Y., \& Berghofer, E. (1999). Extrusion cooking of rice flour and amaranth blends. LWTFood Science and Technology, 32(2), 79-88.

Jin, Z., Hsieh, F., \& Huff, H. E. (1995). Effects of soy fiber, salt, sugar and screw speed on physical properties and microstructure of corn meal extrudate. Journal of Cereal Science, 22(2), 185194.

KC, Y., Dhungana, P. K., \& Subba, D. (2013). Effects of incorporation of millet flour and extrusion conditions on the lateral expansion and bulk density of corn grit-rice grit-chickpea flour blend expanded extrudates. Food Wave, 1, 10-16.

Meng, X., Threinen, D., Hansen, M., \& Driedger, D. (2010). Effects of extrusion conditions on system parameters and physical properties of a chickpea flour-based snack. Food Research International, 43(2), 650-658.

Mezreb, K., Goullieux, A., Ralainirina, R., \& Queneudec, M. (2003). Application of image analysis to measure screw speed influence on physical properties of corn and wheat extrudates. Journal of Food Engineering, 57(2), 145-152.

Myers, R. H., Montgomery, D. C., \& Anderson-Cook, C. M. (2016). "Response surface methodology: process and product optimization using designed experiments". John Wiley \& Sons. [1118916034].
Onyango, C., Noetzold, H., Bley, T., \& Henle, T. (2004). Proximate composition and digestibility of fermented and extruded uji from maize-finger millet blend. LWT-Food science and Technology, 37(8), 827-832.

Pelembe, L. A. M., Erasmus, C., \& Taylor, J. R. N. (2002). Development of a protein-rich composite sorghum-cowpea instant porridge by extrusion cooking process. LWT-Food Science and Technology, 35(2), 120-127.

Rao, B., Christina, G. D. A., \& A.D, V. (2016). Emerging Opportunities for Extrusion in Millets. Indian Farming, 65, 79-83.

Shirani, G., \& Ganesharanee, R. (2009). Extruded products with Fenugreek (Trigonella foenumgraecium) chickpea and rice: Physical properties, sensory acceptability and glycaemic index. Journal of Food Engineering, 90(1), 44-52.

Wen, L. F., Rodis, P., \& Wasserman, B. P. (1990). Starch fragmentation and protein insolubilization during twin-screw extrusion of corn meal. Cereal Chemistry, 67(3), 268-275.

Yadav, K. C., Mishra, P., Dhungana, P. K., Rajbanshi, R., Gartaula, G., \& Dhital, S. (2015). Effects of incorporation of cassava flour on characteristics of corn grit-rice grit-chickpea flour blend expanded extrudates. African Journal of Food Science, 9(8), 448-455.

How to cite: KC, Y., Rajbanshi, R., Bhattarai, P., Dhungana, P. K., \& Subba, D. (2020). Process Optimization of Finger Millet Incorporated Extrudates. Himalayan Journal of Science and Technology, 3-4, 60-67. 